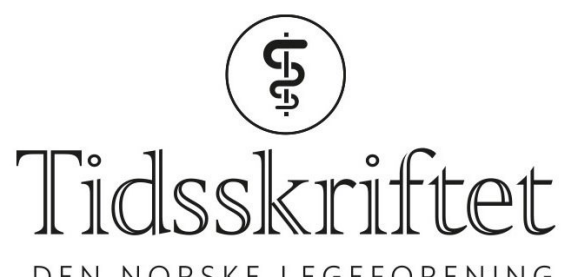

\title{
Tvil om studiefunn ved kronisk utmattelsessyndrom
}

FRA ANDRE TIDSSKRIFTER

ØYVIND STOPLE SIVERTSEN

Tidsskriftet

Dataene fra PACE-studien er analysert på nytt. Det gir andre resultater enn de tidligere publiserte.

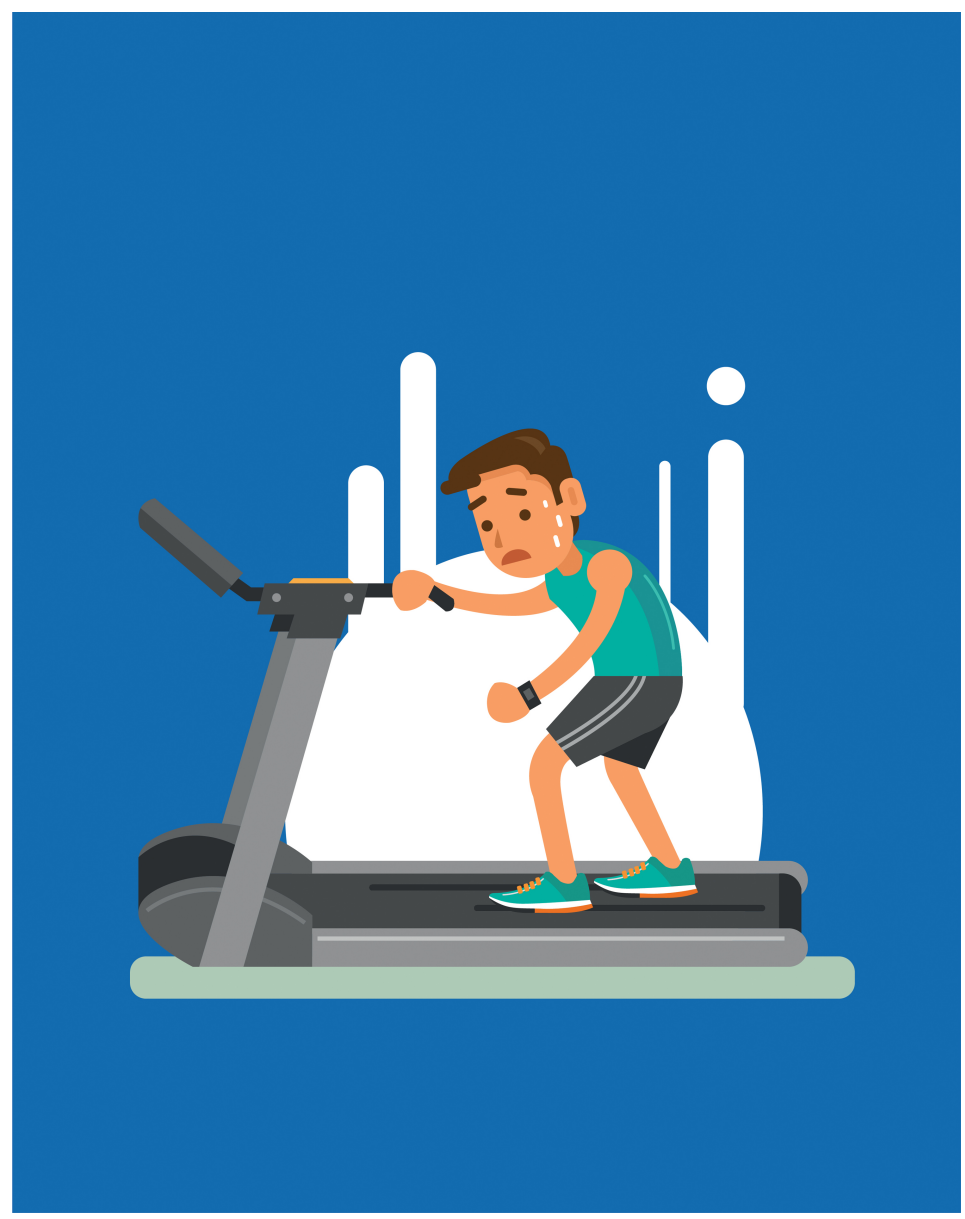

Illustrasjonsfoto: konggraphic/iStock

Resultatene fra den såkalte PACE-studien ble publisert i tidsskriftet The Lancet i 2011 (1). Dette var historiens største undersøkelse av behandling av kronisk utmattelsessyndrom, ofte forkortet CFS/ME. Konklusjonen den gang var at pasientene hadde effekt av både kognitiv atferdsterapi og gradert treningsterapi. Det kom etter hvert mye kritikk mot 
studiens design og andre metodologiske svakheter. Spesielt ble det påpekt at de primære endepunkter var endret fra den opprinnelige studieprotokollen.

I en studie som nylig er publisert $i$ BMC Psychology, er data fra PACE-studien analysert på nytt, denne gang med primære endepunkter som angitt i studieprotokollen (2). Resultatene viste nå færre effekter av kognitiv atferdsterapi og gradert treningsterapi enn det som ble beskrevet i den første artikkelen (1). Forfatteren trekker i tvil grunnlaget for konklusjonen, altså at noen pasienter med kronisk utmattelsessyndrom har en positiv, varig effekt av kognitiv atferdsterapi eller gradert treningsterapi.

- Den nye analysen viser nødvendigheten av å gjennomføre kliniske studier som planlagt, ettersom endringer underveis og i etterkant vil kunne svekke studiens betydning, sier Jone Furlund Owe, som er overlege ved Nevrologisk avdeling, Haukeland universitetssykehus, der han har ansvar for utredning av pasienter med mulig kronisk utmattelsessyndrom.

Owe synes at kritikken som fremkommer i den nye artikkelen er rimelig, men at funnene må bekreftes av flere studier. Han påpeker også at all informasjon fra PACE-studien ikke var tilgjengelig for forfatterne, noe som svekker analysene.

- I sin konklusjon oppfatter jeg at de gjør samme feil som forfatterne av PACE-studien - de trekker konklusjonen om at tiden nå er inne for å se på andre effektive behandlinger ved kronisk utmattelsessyndrom. Den nye analysen kan ikke fastslå at det ikke finnes positiv effekt av kognitiv atferdsterapi og gradert eksponeringsterapi, den påpeker kun svakheter i PACE-studien, sier han.

\section{LITTERATUR:}

1. PACE trial management group. Comparison of adaptive pacing therapy, cognitive behaviour therapy, graded exercise therapy, and specialist medical care for chronic fatigue syndrome (PACE): a randomised trial. Lancet 2011;377: 823-36. [PubMed][CrossRef]

2. Wilshire CE, Kindlon T, Courtney R et al. Rethinking the treatment of chronic fatigue syndrome-a reanalysis and evaluation of findings from a recent major trial of graded exercise and CBT. BMC Psychol 2018; 6: 6. [PubMed][CrossRef]

Publisert: 21. august 2018. Tidsskr Nor Legeforen. DOI: 10.4045/tidsskr.18.0448

(C) Tidsskrift for Den norske legeforening 2020. Lastet ned fra tidsskriftet.no 